\title{
A Sapiência e as Sete Artes Liberais Segundo Hugo de São Vítor
}

\author{
Wesley Rodrigues Athayde
}

\section{Resumo}

Quando, no século XII, Hugo de São Vítor reformula o conteúdo do ensino filosófico, dividindo-o em quatro grandes ciências: lógica, prática, mecânica e teórica, ele o faz com o objetivo de conduzir o homem ao conhecimento das coisas divinas. As três primeiras ciências (prática, mecânica e lógica), ele direciona para orientar o homem em sua vida natural e a última, a ciência teórica, para conduzi-lo ao conhecimento supremo. Segundo Hugo de São Vítor, a ciência teórica constitui "uma via especial para se chegar ao conhecimento da sabedoria divina". Ele a considera como a ciência que investiga a verdade das coisas. Portanto, tendo o homem conhecimento das artes que constituem essa ciência, teria condições de alcançar a sabedoria perfeita, ou seja, a sapiência divina.

Palavras-chave: Sapiência, artes liberais, leitura. 


\section{A Sapiência (Mente de Deus)}

O ensinamento primordial do Didascálicon de Hugo de São Vítor é um convite aos jovens alunos da época a buscar a Sapiência, a Mente de Deus, o renovo do espírito, do homem: "De todas as coisas a serem buscadas, a primeira é a Sapiência, na qual reside a forma do bem perfeito" .

Mas como Hugo São Vítor enxerga essa Sapiência? Para ele, a Sapiência é a essência primordial da qual brotam todas as coisas, uma essência geradora que se torna prenha, proporcionando o nascimento de tudo que existe no universo. Como a razão divina está dentro do homem e o ilumina, Ela faz com que ele tenha uma tendência natural a buscar esse renovo, ou seja, caminhar em direção à Sapiência.

Para Hugo de São Vítor, a Sapiência é a razão organizadora de todas as coisas que existem e se apresenta como a forma primeira de todas as formas, pois dela nasceu tudo que existe no universo, ou seja, tudo que existe criado originase de um arquétipo, ou de uma forma primeira.

Ele sustenta que a alma humana é por natureza dividida em sentido e inteligência. Essa divisão estabelece os modos de sua atuação. Desta forma, o homem atua pelos sentidos quando se aplica às coisas sensíveis (razão humana), tratando de sua manutenção e preservação no mundo material, e pela inteligência (razão divina), quando almeja as coisas intelectíveis, a Mente Divina: "Dividida a alma, ela reúne o seu movimento em dois círculos"2, "pois, seja que pelos sentidos ela se volte para as coisas sensíveis, seja que pela inteligência ascenda às coisas invisíveis, ela circula trazendo para si a semelhança das coisas" 3 .

Parece que, para o vitorino, a alma possui o conhecimento do espírito e da matéria sensível (conhecimento divino e conhecimento material, que diz respeito ao homem). O conhecimento dessas duas partes está intrínseco na alma humana, embora muitos, não se apercebendo disso, conservam apenas o conhecimento das coisas sensíveis, ignorando que haja um outro conhecimento superior do que é inteligível.

Como o conhecimento da Sapiência está acima de qualquer sabedoria, seja ela ligada às artes técnicas e seu exercício, seja ligada ao conhecimento das coisas divinas, cabe à filosofia (que trata e vai além dessas duas partes) certa aproximação

\footnotetext{
I Hugo de São Vítor. Didascálicon da arte de ler. Petrópolis: Editora Vozes, 200I, I, p. 47.

2 Boethius. Anicii Manlii Boethii Philosophiae Consolatio 3. m9.

3 Hugo de São Vítor. Didascálicon da arte de ler. Petrópolis: Editora Vozes, 200I, I, p. 49.
} 
e manutenção da amizade com a razão primordial: "A filosofia é, portanto, o amor, a procura e certa amizade com a Sapiência, mas não aquela sabedoria que se ocupa de ferramentas e de ciências produtivas, e sim aquela Sapiência que, não carecendo de nada, é mente viva e "única razão primordial das coisas"4.

Para Hugo, quando o homem está filosofando, a Mente de Deus está iluminando sua mente; todo o desenvolvimento de idéias e pensamentos que chega ao filósofo e que será apresentado ao mundo tem origem na Mente Divina. O ato de assemelhar-se à Sapiência é que proporciona ao filósofo esta iluminação e a proximidade dele com Deus se torna mais intensa, transformando-o num manancial de sabedoria e excelência no que diz respeito à razão humana.

\section{A Razão Humana (Ratio)}

A investigação da busca da Sapiência em Hugo de São Vítor pode partir do conceito que ele estabelece para a razão (ratio). No Didascálicon, é tratada logo no primeiro livro, no cap. 3, a razão humana, mas Hugo procura situá-la na ordem de todos os viventes. Essa ratio, privilégio do homem, Hugo associa a duas outras potências: a primeira para manutenção e preservação do corpo humano, a segunda para controle das percepções sensíveis, ou seja, permitir que o homem arbitre sobre as coisas corretamente; e uma terceira potência, de âmbito divino, que vai orquestrar corretamente os atos e pensamentos humanos conforme a excelência da sabedoria de Deus ${ }^{5}$.

Ele apresenta a razão como tendo no homem seu habitat natural, estando ela contida intrinsecamente na alma humana e sendo ela o único caminho para a regeneração do estado caótico em que se encontra a humanidade. Não obstante, devido à condição do homem nesse mundo material em que as paixões o distraem, essa ratio divina depositada nas profundezas de sua alma, sofre constantes combates pelas formas sensíveis que "aqui" existem, causando ferimentos em seu corpo e em seu espírito ( $c f$. Didascálicon I, 5).

\footnotetext{
4 Hugo de São Vítor. Didascálicon da arte de ler. Petrópolis: Editora Vozes, 200I, I, 2 p. 53.

5 "Em geral, pode ser detectada uma potência tríplice da alma em sustentar os corpos. Uma confere ao corpo somente a vida, para que, nascendo, cresça e, alimentando-se, continue a viver. A segunda oferece a capacidade de discernimento mediante a percepção sensível. A terceira é dotada da força da mente e da razão". idem. ib. II, 3, p.55. Em outros viventes, que não o homem, aparecem apenas a primeira potência nos vegetais e a primeira e segunda nos animais.
} 
Porém, o filósofo sustenta que, se o homem, pelo esforço e disciplina, empenhar-se em um combate contra as coisas sensíveis, apegando-se cada vez mais às coisas divinas ou intelectíveis, alcançará a felicidade tanto para o corpo como para a alma. Pois, segundo Hugo de São Vítor, "Todas estas almas, tendo já feito parte daquela substância intelectível primordial, pelo contato com os corpos degeneraram de intelectíveis para inteligíveis, de modo que elas, agora, mais que serem conhecidas, conhecem, e, em virtude da pureza da inteligência, se tornam tanto mais felizes, quanto mais se aplicam às coisas intelectíveis" ${ }^{\text {. }}$

Essas potências da alma, que se apresentam no homem, têm dois objetivos: o primeiro, de preservar sua vida material; é a sobrevivência e se refere a ações humanas do domínio do que Hugo chama a ciência. O segundo, de conduzir o homem ao conhecimento das coisas divinas, domínio da inteligência. É por esse motivo que o vitorino estabelece no Didascálicon a divisão das artes em quatro partes; três delas para orientar a razão humana (prática, mecânica e lógica), e uma para conduzi-lo ao divino (teórica).

Assim sendo, as ciências, que constituem a filosofia, são uma preparação (costumes e trabalhos) para o homem chegar ao seu maior objetivo, que é a Sapiência. É como se as três primeiras ciências juntas (a mecânica, a lógica e a prática) contivessem uma espécie de aparato que proporciona ao homem uma base disciplinar que vai desde a manutenção e preservação de seu corpo até sua postura perante a família e a sociedade, o desenvolvimento do trabalho e o bom uso da palavra. Somente com o equilíbrio e harmonia nessas ciências é que o homem poderá iniciar sua jornada em direção à Sapiência. Essa excelência nos atos humanos se aplica nas ciências praticas, mecânicas e se estende até a ciência lógica, tendo o homem, portanto, condições de preparar-se para receber o conhecimento da ciência que é considerada por Hugo de São Vítor a doce Sapiência: a teórica.

\section{As Sete Artes Liberais}

Hugo de São Vítor, combinando diversas fontes, divide a filosofia em quatro tipos ou ciências: teórica, prática, mecânica e lógica. Cada uma dessas partes da filosofia contém, por sua vez, outras diversas ciências. Desde a tríade teórica (teologia, matemática e física) até as artes do trívio (gramática, dialética e retórica), incluídas na lógica. No meio estão o quadrívio (aritmética, geometria, astronomia e música), identificado com a matemática, a tríade prática (ética,

6 Hugo de São Vítor. Didascálicon da arte de ler. Petrópolis: Editora Vozes, 200I, II,3 p. 87. 
econômica e política) e as sete artes mecânicas (lanifício, armadura, navegação, agricultura, caça, medicina e teatro). Embora Hugo desmembre as sete artes liberais, identificando o quadrívio à matemática, uma parte da filosofia teórica, e incluindo o trívio na lógica, continua a lhes atribuir um papel relevante.

De fato, o que é feito é uma inovação na divisão da filosofia, dividindo-a em quatro partes: teórica, prática, mecânica e lógica, tirando o trívio e o quadrívio (as sete artes liberais da Idade Média) da divisão principal da filosofia e colocando-os como subdivisão da lógica e da matemática ${ }^{7}$.

No Didascalicon de studio legendi libri vI (algo como que "Ensinamento sobre a dedicação ao aprendizado pela leitura, em vi livros"), diz ele no livro III, cap. 3:

De todas estas ciências acima enumeradas, os antigos destacaram de modo especial sete delas em seus programas de ensino. Nelas viram tanta utilidade em comparação com todas as outras que, qualquer um que adquirisse firmemente o conhecimento delas, chegaria ao conhecimento das outras, mais pesquisando e praticando do que ouvindo. Elas são como instrumentos pelos quais ao espírito é preparada a via para o pleno conhecimento da verdade filosófica. Por esta razão se chamam "trívio" e "quadrívio", pois por elas, como se fosse por algumas vias, o espírito vivo penetra nos segredos da sabedoria. ${ }^{8}$

Embora Hugo de São Vítor coloque o trívio e o quadrívio como subdivisão da lógica e da matemática - em sua nova divisão da filosofia - em momento algum diminui o valor dessas artes. Sustenta que estas são o fundamento de todo o saber filosófico e possuem entre si uma ligação tão estreita que não há como desprezar uma e abraçar as outras: "Hugo pensa que todas as disciplinas são solidárias: se falta uma delas todas as outras não farão um filósofo... Prender-se a algumas ciências particulares, abandonando as outras, não pode conduzir à verdadeira sabedoria" 9 .

Com razão, entendem-se essas artes como membros que formam um único corpo e, faltando um dos membros, o corpo se torna debilitado, deixando seu estado perfeito e tornando-se defeituoso e incompleto. Sem uma dessas artes a filosofia deixa de ser filosofia e consequentemente deixa de produzir filósofos: "Na verdade, o fundamento de todo o saber está nas sete artes liberais, as quais, mais que as outras, devem estar à mão, como aquelas sem as quais a disciplina

7 Vide anexo I.

8 Hugo de São Vítor. Didascálicon da arte de ler. Petrópolis: Editora Vozes, 200I, III, 3, p. I37. Rosa Luxemburgo.

9 Édouard Jeaneau. A filosofia medieval. Lisboa: Edições 70 p. 57. 
filosófica nada costuma ou pode explicar e definir. Elas são tão conexas entre si e necessitam tanto dos fundamentos recíprocos uma da outra, que, se apenas uma faltar, as outras não podem produzir um filósofo"

\section{A Filosofia}

No Didascálicon, a filosofia é definida como "a disciplina que investiga exaustivamente as razões de todas as coisas humanas e divinas" ${ }^{I I}$.

Hugo de São Vítor a divide em quatro ciências: a ciência teórica, ciência prática, ciência mecânica e ciência lógica. Essa divisão apresentada por Hugo de São Vítor difere da divisão de Boécio, por nesta não conter a ciência mecânica: "Boécio distingue três espécies de Filosofia, a saber: a especulativa, que se ocupa da natureza das coisas a ser investigada; a moral, que se ocupa da dignidade da vida a ser considerada; a racional, denominada lógica pelos gregos, que se ocupa da ordem dos argumentos a serem compostos" ${ }^{2}$.

No início do livro, é apresentada uma citação de Boécio asseverando que: "A filosofia é, portanto, o amor, a procura, e certa amizade para com a sabedoria, mas não aquela sabedoria que se ocupa de algumas ferramentas, e de alguma informação e ciência fabril, e sim aquela sabedoria que, não carecendo de nada, é mente viva e única razão primordial das coisas" 13 . Todavia, Hugo esclarece que o que Boécio assevera é que o campo de atuação da filosofia se estende a todas as ciências no que tange aos princípios teóricos, não se aplicando à realização prática, ou seja: os atos pensados cabem à filosofia e o atos executados às ciências técnicas e produtivas ( $c f$. Didascálicon $\mathrm{I}, 4)$.

"Ora, Boécio não chama de filosofia qualquer ciência, mas apenas a que se detém nas coisas mais elevadas" "I4. Sendo, a filosofia o amor, a procura e a amizade com a sabedoria, mesmo não estando o conhecimento de ferramentas e ciências produtivas em seu âmbito, abrange todas as ciências, pois, antes da execução por meio de ferramentas tem que haver o ato de pensar e este pertence à filosofia. Dessa forma, Hugo de São Vítor considera o trabalho humano como parte da filosofia, pois, por seu aspecto teórico, em que o homem volta seus olhos para as formas

IO Hugo de São Vítor. Didascálicon da arte de ler. Petrópolis: Editora Vozes, 200I, III, 4, p. I43.

II idem. ib. I, 4, p. 59.

I2 Pedro Abelardo. In: Lógica para principiantes, p. 39.

I3 Hugo de São Vítor. Didascálicon da arte de ler. Petrópolis: Editora Vozes, 200I, I, 2 p. 53.

I4 Pedro Abelardo. In: Lógica para principiantes, p. 39. 
exemplares e só então as estendem à execução da obra, imitando a natureza, idéia divina, esse trabalho passa a ter uma dimensão filosófica (cf. Didascálicon I, 4,9 e IO).

Observa-se no Didascálicon que toda a ação é divina ou humana: quando a ação é de âmbito divino, se faz presente a inteligência; quando é de âmbito humano, a ciência se apresenta. Como a Sapiência guia todas as ações do homem, cabe à filosofia estudar tanto a ciência quanto a inteligência, tanto os atos humanos quanto os atos que buscam o conhecimento da divindade.

\section{Sobre as Ciências que Compõem a Filosofia}

A nova divisão da filosofia apresentada por Hugo de São Vítor compõe-se de vinte e uma disciplinas e, levando-se em considerações os vários níveis dessa divisão, esse número chega a vinte e oito ${ }^{\mathrm{I}}$.

De fato, essas ciências ou artes não foram construídas ou elaboradas por Hugo de São Vítor, elas nasceram em lugares diferentes e por grande variedade de autores.

A Grécia contribuiu com Lino na teologia; Tales de Mileto na física natural; na aritmética, Pitágoras de Samo; na música aparecem Lino, Zeto, Anfião e Pitágoras; na geometria, Euclides e Erastóstenes. Atlas foi quem idealizou a astronomia (daí o mito de ele sustentar o céu); na ética, Sócrates e Platão; na mecânica, Hesíodo de Ascre, Demócrito e Mago; na fabricação da lã, Minerva e Dédalo; no uso do trigo, Ceres; na medicina, Apolo e, quinhentos anos depois, Hipócrates, isso porque depois de Apolo não se deu muita atenção à medicina. O alfabeto grego foi elaborado pelos fenícios; Darete escreveu a história de Tróia; Heródoto foi o primeiro historiador, depois Ferécide; na dialética têmse Parmênides. "Platão, por sua vez, após a morte de seu mestre Sócrates, movido pelo amor da sabedoria, emigrou para o Egito, e de lá, após ter aprendido as artes liberais, voltou a Atenas, onde, tendo reunido os discípulos na Academia, que era a casa dele, dedicou-se aos estudos da filosofia" ". Platão ensinou a lógica racional aos gregos, depois foi ensinada por Aristóteles, seu discípulo, e a retórica iniciou-se com Demóstenes.

Do povo hebreu, Tubal, da estirpe de Caim, contribuiu com a música, parece que Cam, filho de Noé, teria iniciado o estudo de astronomia e Abraão teria sido o primeiro a formar os egípcios em astrologia. $O$ alfabeto

I5 Vide anexo I.

I6 Remigius de Auxerre, Commentum in Martianum Capellam 4,2. 
hebraico foi construído por Moisés e o alfabeto dos caldeus e dos sírios por Abraão. Moisés teria sido o primeiro a escrever uma história divina.

Os Caldeus teriam sido os primeiros a ensinar astrologia. Roma contribuiu nas artes mecânicas com Catão e Marco Terêncio. Os egípcios contribuíram com a geometria; Ptolomeu, rei do Egito, reorganizou a astronomia; Isis e Osíris deram sua contribuição na fabricação da lã, no uso do trigo e em seu tempo foi inventada a gramática. "O Egito é a mãe das artes, que de lá vieram para Grécia e depois para a Itália" ${ }^{17}$.

$\mathrm{Na}$ Idade Média surgiu o teólogo João Escoto; a física teve Plínio; a aritmética foi traduzida por Apuleio e Boécio, que também traduziu as obras de Euclides; na ética, Cícero organizou os livros sobre a República em latim e Fronto escreveu sobre a conduta militar; no uso do trigo se destacaram Piluno e Tago. Carmenta, mãe de Evandro, inventou o alfabeto latino, Marco Terêncio Varro traduziu a dialética do grego para o latim, Gícero elaborou os tópicos. A retórica iniciou-se com Tísia, e foi traduzida do grego para o latim por Túlio, Quintiliano e Ticiano.

São estes os possíveis autores das artes apresentados por Hugo de São Vítor. Percebe-se - como no caso da Grécia antiga - que os autores de algumas artes estão relacionados com personagens da mitologia grega, como no caso da arte de fabricação da lã que foi ensinada aos gregos por Minerva.

\section{O Fruto da Leitura Divina}

As Sagradas Escrituras podem ser apresentadas ou entendidas de três modos diferentes: o modo histórico, o alegórico e o moral. Todavia, nem todos os escritos bíblicos contêm esse três modos de interpretação: uns podem interpretar-se apenas historicamente, outros apenas alegoricamente e outros apenas moralmente. Pode acontecer que em alguns escritos possamos interpretá-los das três maneiras (histórica, moral e alegórica).

Além do significado das palavras, no elóquio divino encontramos o significado das coisas que é de uma excelência muito maior que o das palavras, pois foi prescrito pela natureza: "A palavra é a voz do homem, a coisa é a voz de Deus"

Quanto à maneira especial de falar das escrituras sagradas, Hugo de São Vítor apresenta sete regras para proferi-la: a primeira regra diz respeito ao senhor

I7 Hugo de São Vítor. Didascálicon da arte de ler. Petrópolis: Editora Vozes, 200 I, III, I, p. I37. I8 idem. ib. v, 3, p. 209. 
e seu corpo, a segunda regra pertence ao corpo verdadeiro e ao corpo misto do Senhor, a terceira concerne à letra e ao espírito ou a lei e a graça, a quarta regra refere-se à espécie e ao gênero, a quinta regra diz respeito ao tempo, a sexta pertence à recapitulação e, finalmente, à sétima regra concerne o diabo e seu corpo. No livro V, capitulo 4 do Didascálicon, Hugo de São Vítor expõe com minúcia cada uma dessas regras, esclarecendo de tal forma que o estudante possa assimilá-las, compreendê-las e colocar como adjunto em sua mente e coração.

Todavia, se a leitura das Escrituras Divinas enriquece o conhecimento, para que o aluno colha o fruto dessa leitura não é necessário somente ler os textos sagrados, mas ter conhecimento do modo e da ordem de leitura, ou seja, além do modo, ter um método a ser aplicado, para que seu estudo avance. Nesse palmilhar - segundo Hugo de São Vítor - para que o aluno entenda com mais facilidade as coisas que devem ser feitas, é necessário, antes, que ele entenda o que não se deve fazer.

Existem três coisas que impedem o aluno a progredir nos estudos, a saber: a negligência, a imprudência e a má sorte. A negligência é estudar sem afinco, dedicação e amor, ela está relacionada com a displicência; já a imprudência ocorre quando não há ordem e o método apropriado de estudo não é o correto; finalmente, a má sorte ocorre em situações em que o aluno é impossibilitado de prosseguir nos estudos devido a problemas de saúde, dificuldade financeira, retardo mental ou escassez de professores. Por essa razão, Hugo de São Vítor esclarece que num grande número de alunos que se destacam pelo emprenho e pelo trabalho, poucos conseguem chegar verdadeiramente ao saber: "Direi logo qual é a razão pela qual numa grande massa de estudantes, muitos dos quais se destacam pelo engenho, e se dedicam com afinco ao trabalho, tão poucos, que podem ser contados nos dedos, conseguem chegar ao saber" ${ }^{19}$. Logo em seguida, Hugo de São Vítor responde que a razão desse insucesso deve-se à aplicação e o método da aplicação usados de maneira incorreta no trabalho. Se não há essas duas $\operatorname{coisas}^{20}$, o trabalho não avança, o estudante está fadado à frustração, ou seja, a trabalhar muito e nunca alcançar verdadeiro saber:

Repare em duas pessoas atravessando o bosque, uma suando através de desvios, a outra escolhendo os atalhos de um traçado reto: fazem o percurso com o mesmo ritmo, mas não chegam no mesmo tempo. E o que denominaria eu a Escritura senão uma floresta, cujas frases colhemos na leitura como se fossem frutos dulcíssimos e as ruminamos na

Ig Hugo de São Vítor. Didascálicon da arte de ler. Petrópolis: Editora Vozes, 200I, v, 5, p. 2 I7.

20 Aplicação e método de aplicação.

Humanidades em Diálogo, vol i, N. I, nov. 2007 
reflexão? Aquele, portanto, que em tão grande multidão de livros não mantém um método e uma ordem de leitura, este, como se vagueasse na densidade da floresta, perde o caminho do percurso certo, sempre estudando - como se diz - nunca chegando ao saber.

Todo trabalho que Hugo de São Vítor apresenta sobre o aprendizado e a leitura dos textos divinos tem um resultado a ser alcançado. Os frutos da leitura divina são proporcionar conhecimento e bons costumes à mente.

Como visto anteriormente, as Sagradas Escrituras podem ser apresentadas ou entendidas de três modos diferentes: o modo histórico, o alegórico e o moral. O conhecimento adquirido com a leitura dos textos sagrados está relacionado com a história e a alegoria, e os bons costumes com a tropologia, ou seja, o emprego da linguagem figurada ou alegoria moral.

De fato, a maneira como Hugo de São Vítor apresenta o caminho para o conhecimento divino ${ }^{21}$ no Didascálicon é maravilhosa: na divisão das ciências que constituem a Filosofia, ele distingue as artes que preservam a vida do homem na terra $^{22}$ das que investigam a verdade das coisas ${ }^{23}$, ou seja, que levam o homem ao verdadeiro conhecimento das coisas. $\mathrm{O}$ aparato que sustenta e faz o homem avançar no conhecimento das artes é a leitura e o aprendizado das Escrituras Sagradas - tarefa que pertence à teologia - e seu fruto vai além de viabilizar o conhecimento das artes: ele prepara o homem para o retorno a seu estado primordial e divino.

Anteriormente foi exposto que o resultado da leitura das Escrituras Sagradas era o conhecimento e bons costumes da mente. Ter bons costumes é conhecer as virtudes e as regras para uma boa vida e, para tal intento, Hugo de São Vítor propõe a leitura dos livros do sacro elóquio, que aconselham o total despojamento das paixões deste mundo, a vida no amor a Deus e como peregrino e estrangeiro neste mundo, procurar primeiros às coisas de Deus, pois as demais Ele se encarrega de nos dar ${ }^{24}$, ou seja, estar buscando constantemente o caminho de volta à nossa pátria verdadeira.

A leitura das ações dos santos e a aprendizagem concernente à nossa vida disciplinada são caminhos para alcançar esse objetivo, porém o homem que

2I A Sapiência.

22 As artes pertencentes às ciências mecânica, lógica e prática (vide anexo I).

23 As artes pertencentes à ciência teórica (vide anexo I).

24 "Mas buscar primeiro o reino de Deus e sua justiça, e todas estas coisas vos serão acrescentadas". (Evangelho de São Mateus, cap. 6.33). 
desejar palmilhar esse caminho deve ter moderação na leitura, ler as Escrituras para a edificação de sua vida, estudar não a literatura, mas as virtudes que há na leitura e esta deve ser motivo não de aborrecimento, mas de alegria e contentamento. Ler as escrituras apenas como ocupação e aflição de espírito é estar distante de fazer filosofia: "Para o filósofo cristão a leitura deve ser uma exortação, não uma ocupação, e deve nutrir os bons desejos, não matá-los” ${ }^{25}$, pois a leitura feita de maneira incorreta causa aflição de espírito pela qualidade se for muito obscura e pela quantidade se for muito longa.

Essas orientações de Hugo de São Vítor não são apresentadas como repreensões à diligência dos que lêem, mas expostas para orientar o que ler, ensinar a melhor maneira de ler e mostrar que aqueles que aprendem são dignos de louvor. Embora seja esse o objetivo das orientações de Hugo de São Vítor sobre a leitura das Escrituras, nem todos a lêem com esse objetivo: uns a lêem apenas para seu conhecimento ou adquirir riquezas, também para se obter fama e honra e as intenções são pouco dignas; outros porque têm prazer em ouvir as palavras de Deus, não porque conduzem à salvação ou para desfrutarem de suas maravilhas, mas sim, para terem o prazer de conhecer e expor esse conhecimento com orgulho sem amor à misericórdia: "Que outras coisas estes fazem, diria eu, senão transformar os anúncios divinos em fábulas?" 26 . Finalmente, há os que lêem as escrituras com o objetivo de aniquilar os inimigos da verdade, ensinar o amor e a verdade. Estes são os justos e suas vidas se alicerçam em cinco coisas: a leitura ou instrução, a meditação, a oração, a pratica e a contemplação.

De fato, no final do capitulo v do Didascálicon, Hugo de São Vítor apresenta os cinco degraus que o homem deve alcançar em sua vida na terra, sendo o quinto degrau o fruto dos quatro precedentes, o prêmio dessa soberana vocação "(...) o primeiro degrau, a leitura, dá o entendimento; o segundo, a meditação, engendra o discernimento; o terceiro, a oração, pede; o quarto, a prática, procura; o quinto, a contemplação, encontra" ${ }^{27}$.

Hugo de São Vítor encerra seus ensinamentos sobre a arte de ler relembrando quais os âmbitos em que se dá a ordem da leitura: disciplina, livro, narração e exposição; os três métodos de interpretação da escritura: interpretação histórica em sua ordem temporal, interpretação alegórica segundo a ordem de conhecimento, interpretação tropológica com atenção voltada mais às coisas que as palavras; e, ao final, ele expõe suas reflexões sobre os termos letras, significado, sentença e medição.

25 Hugo de São Vítor. Didascálicon da arte de ler. Petrópolis: Editora Vozes, 200I, V, 7 p. 22 I.

26 idem. ib. v, IO, p. 233.

27 idem. ib. v, 9, p. 229. 
No estudo é necessário que se aprenda antes de tudo a história e a verdade dos fatos que a fizeram acontecer. Para tal intento, se faz necessário seguir determinados passos: primeiro, verificar na história o que foi feito, para depois investigar quando foi feito, onde foi feito e, finalmente, por quais pessoas foi feito. Hugo de São Vítor enfatiza que no estudo não se deve desprezar nenhuma informação, pois nas mínimas coisas há algo a ser aprendido "Aquele que despreza as coisas mínimas, aos poucos definha" ${ }^{28}$, "Aprenda tudo, e verá depois que nada é supérfluo. O saber limitado não é alegre" ${ }^{29}$.

Quando o filósofo vitorino apresenta a importância do conhecimento da história, refere-se à história das Sagradas Escrituras e enfatiza que todos os livros são importantes conhecer, porém a alguns ele atribui - devido ao seu conteúdo - maior importância: "Você me pergunta se eu tenho algumas sugestões sobre os livros que são úteis para esse tipo de leitura. Acho que devem ser estudados mais estes: Gênesis, Josué, o livro dos Juízes, dos Reis e o livro das Crônicas. Quanto ao Novo Testamento, primeiro os quatro Evangelhos, depois os Atos dos Apóstolos”. A leitura desses livros deve ser feita sobre tudo com ordem. Na desordem, nada será agregado ao conhecimento do aluno, ao passo que, na organização, os frutos da leitura serão colhidos. Na história é que se admiram os fatos de Deus. Ela é o princípio e fundamento da ciência sagrada e dela é engendrada a verdade da alegoria.

No Didascálicon, ele faz uma analogia da história e alegoria com as fundações de uma construção: "A fundação sob a terra, como dissemos, afigura a história, o edifício que é construído em cima sugere a alegoria. Por essa razão, a própria base deste edifício deve relacionar-se com a alegoria" ${ }^{\circ}$.

Como num edifício, vários planos são levantados. Também nas páginas divinas esses planos são apresentados amalgamados com seus devidos mistérios.

Hugo de São Vítor enfatiza que são oito os planos contidos na Escritura Sagrada: o primeiro plano é o mistério da Trindade, ou seja, a existência de um Deus uno e trino antes de qualquer outra existência; o segundo plano é a criação de todas as criaturas, sejam visíveis ou invisíveis; o terceiro plano enfatiza o que é o pecado, qual sua origem e punição; o quarto plano são os sacramentos instituídos na origem sob a lei natural para a reparação do homem; o quinto plano são os escritos sobre essa lei; o sacramento sobre a encarnação do verbo é

28 Hugo de São Vítor. Didascálicon da arte de ler. Petrópolis: Editora Vozes, 200 , VI, 3, p. 237.

29 idem. ib. VI, 3, p. 239.

30 idem. ib. VI, 4 , p. 245 . 
o sexto plano; os sacramentos do Novo Testamento pertencem ao sétimo plano; e, finalmente, no oitavo plano tem-se o mistério da ressurreição.

Hugo apresenta, nesses oito planos, todo o mistério da divindade, sendo suas bases os próprios princípios desses mistérios.

A leitura é o caminho para desvendar esses mistérios e para edificação do edifício espiritual, porém, para tal intento, Hugo de São Vítor adverte para uma série de cuidados a serem tomados pelo aluno para que todo trabalho de leitura e aprendizado não venha a tomar rumos contrários à edificação espiritual. $\mathrm{O}$ aluno deve instruir-se sobre cada ponto relativo ao seu intento e à profissão da verdadeira fé, aprender primeiro aquilo que deve professar com segurança e crer verdadeiramente, as coisas que são ambíguas devem ser interpretadas de modo que não se contradigam e as que são obscuras devem, na medida do possível, ser elucidadas.

Aquilo que o aluno não conseguir desvendar pelo entendimento deve ser ignorado e ele deve prosseguir, precavendo-se desta forma de correr risco de interpretar as coisas erroneamente. Não deixar que as coisas contrárias à fé firmíssima venham mudar a opinião. Hugo de São Vítor também adverte sobre o perigo da letra "A letra mata, o Espírito dá a vida" ${ }^{\mathrm{I}}$, tendo o estudante que estar "consolidado pela verdade da inteligência espiritual" ${ }^{2}$, para que a letra não venha a corrompê-lo e possa ele distinguir a letra que é boa das que são perversas: "É necessário, portanto, que sigamos, sim, a letra, mas de maneira a não preferir o nosso sentido ao dos escritores divinos, e não devemos segui-la sem crer que nela está depositado todo o juízo da verdade”. Encerrando as instruções, Hugo de São Vítor adverte que o estudante não deve presumir instruir-se sozinho e, sim, auxiliar-se com os doutores e sábios, para que não acredite estar se iniciando, quando na verdade pode estar se seduzindo.

Quanto à tropologia ou moralidade, Hugo de São Vítor enfatiza que ela deve relacionar-se mais com o significado das coisas, pois nestas encontra-se a justiça natural que dá origem à disciplina moral ou justiça positiva: "Contemplando aquilo que Deus fez, conhecemos aquilo que devemos fazer. A natureza inteira fala de Deus, toda natureza ensina ao homem, toda natureza produz a razão, e nada no universo é infecundo"33.

Quanto à ordem dos livros, há uma diferença entre a leitura histórica e a leitura alegórica, pois a histórica segue a ordem do tempo e a alegórica, a ordem do conhecimento.

3I Segunda Epístola do Apóstolo São Paulo Aos Corintios 3, 6.

32 Hugo de São Vítor. Didascálicon da arte de ler. Petrópolis: Editora Vozes, 200I, VI, 4, p. 25I.

33 idem. ib. VI, 5, p. 25I. 
De fato, como foi enfatizado anteriormente, o estudo deve iniciar-se sempre das coisas claras e não das obscuras. Logo, segundo Hugo de São Vítor a leitura do Novo Testamento, deve ser feita antes do Velho Testamento pois nela é anunciada a verdade manifesta, ao passo que no Velho Testamento, tal verdade está anunciada envolta de imagens e de maneira oculta. No Velho Testamento, a verdade é uma promessa que se cumpre no Novo Testamento, pois sem conhecer o nascimento de Cristo, sua predicação, paixão, ressurreição e ascensão, é impossível penetrar os mistérios das figuras antigas.

Hugo de São Vítor esclarece que, quanto à ordem da narração, os textos das escrituras Sagradas nem sempre observam uma ordem de falar natural e contínua, porém, quanto à ordem da exposição do texto, ele enfatiza que esta contém três elementos, a saber: a letra, o significado e o pensamento. Toda narração deve conter no mínimo dois elementos, porém a letra deve estar sempre presente, pois, segundo Hugo de São Vítor, as próprias vozes são letras. Desta forma, a narração pode também ser constituída de letra e pensamento, (quando, para o entendimento é necessária uma exposição), letra e significado (quando o significado é claro) e de letra, pensamento e significado (quando "(..) algo é significado expressamente ou alguma outra coisa que é revelada por uma exposição é deixada subentendida" ${ }^{34}$ ).

A última instrução que Hugo de São Vítor apresenta no Didascálicon é quanto ao modo de ler. Na leitura das Escrituras Sagradas, a divisão se faz necessária, pois para tal intento é preciso dividir separando e dividir investigando. Dividese separando quando se distingue as coisas que são confusas e divide-se investigando quando se revela as coisas que são obscuras.

Com a apresentação do capitulo I2 do livro vi, O Modo de Ler ${ }^{35}$, Hugo de São Vítor, de uma maneira clara, concisa e brilhante, conclui sua explicação concernente à arte de ler.

\section{Conclusão}

Quando, no século XII, Hugo de São Vítor reformula o conteúdo da filosofia, dividindo-a em quatro grandes partes (teórica, prática, mecânica e lógica), ele o faz com o objetivo de conduzir o homem ao conhecimento das coisas divinas. Para tanto, Hugo de São Vítor direciona três dessas partes

34 Hugo de São Vítor. Didascálicon da arte de ler. Petrópolis: Editora Vozes, 200I, VI, 8, p. 259.

35 idem. ib. VI, I2, p. 265. 
(prática, mecânica e lógica) para orientar o homem na sua vida terrena e uma delas (a teórica) para conduzi-lo no caminho para a Sabedoria Suprema: a Sapiência. Daí o motivo de Hugo de São Vítor chamar de Sapiência somente de a ciência teórica.

Para que o homem chegue ao conhecimento supremo, Hugo de São Vítor julga necessário, primeiro, que ele se prepare quanto ao seu modo de vida terreno, ou seja, que ele tenha princípios morais tanto na sua vida privada quanto na vida pública (conhecimento das artes pertencentes à ciência prática), que ele conheça as técnicas de trabalho para facilitar sua vida (conhecimento das artes pertencentes à ciência mecânica) e que ele saiba se comunicar bem, tanto na escrita como na arte de falar (conhecimento das artes pertencentes à ciência lógica).

Tendo o homem alcançado certa disciplina e harmonia em sua vida terrena, Hugo de São Vítor julga estar ele apto a palmilhar o caminho para o conhecimento da Sapiência. Para tanto, é necessário o conhecimento das artes pertencentes à ciência teórica (teologia, matemática e física).

$\mathrm{Na}$ investigação feita sobre as artes que constituem a ciência teórica, Hugo de São Vítor as considera artes que investigam a verdade das coisas. Essas artes não se preocupam, por exemplo, em manter biologicamente a vida do homem na terra, mas sim em conduzi-lo - através de suas verdades - a um novo caminho que lhe permite chegar à Mente de Deus, o conhecimento perfeito e puro das coisas.

Hugo enfatiza que tanto a teologia, quanto a física, a aritmética, a música, a geometria e a astronomia têm esse objetivo. Buscando-se a verdade das coisas, ou seja, o cerne de onde elas são geradas, chega-se ao conhecimento das coisas supremas, pois é nesse centro, do qual emana a essência de tudo que existe, que se aloja a Sabedoria Suprema. Se o homem chegar a esse nível de conhecimento das coisas, chega à Sapiência Divina.

Para tanto, é necessária certa ordem e método de leitura dessas artes e importante via para realização dessa façanha apresentada por Hugo de São Vítor é a leitura das Escrituras Sagradas com suas particularidades. Afinal, é de suma importância saber como as Escrituras Sagradas devem ser lidas por aqueles que procuram nela o verdadeiro saber.

Hugo de São Vítor apresenta como parte da educação a meditação, porém no Didascálicon - Da arte de ler, apresentado por ele, essa parte é omitida, pois acreditando ele que tamanho argumento merecesse um tratado especial, prefere calar-se totalmente a dizer algo incompleto.

Todavia, se a meditação no âmbito da educação é omitida por Hugo de São Vítor em seu Didascálicon-Da arte de Ler, é possível que ela possa ser investigada em 
outros escritos e por outros filósofos. Hugo de São Vítor a define como algo muito sutil e ao mesmo tempo jucundo, que ensina os principiantes e exercita os mais experientes ${ }^{36}$, mostrando, dessa forma, sua importância e enfatizando que deve ser tratada com merecida atenção.

Como este assunto não se esgota neste trabalho, seria interessante uma investigação mais detalhada e aguçada sobre a meditação no processo de educação, consagração à Sapiência e busca da mesma sob a ótica de um filósofo medieval, como Hugo de São Vítor, e que por certo seria de grande valia e agregaria muito ao conhecimento do homem contemporâneo.

\section{Referências Bibliográficas}

São Vitor, Hugo de. Didascálicon: Da arte de ler. Petrópolis: Editora Vozes, 200I. $277 \mathrm{p}$.

SAint-Victor, Hugo de. L'Art de lire: Didascalicon. Paris, I99I. 238 p. (Sagesses chrétiennes. Intr., trad. et notes par Michel Lemoine).

St. Vicotor, Hugh of. On the Sacraments of the Christian Faith (De Sacramentis). Cambridge: The Mediaeval Academy of America, Trad. Roy J. Deferrari, I95I.

BARON, R. Science et Sagesse chez Hugues de Saint-Victor. Paris: P. Lethielleux, Éditeur, I957. $280 \mathrm{p}$.

BARON, R. "L'insertion des arts dans la philosophie chez Hugues de SaintVictor". In: Arts libéraux et philosophie au Moyen Âge. Paris: Montréal: Institut d'études médiévales; Paris: Lib. Phil. J. Vrin, I967.

Mongelli, L. M. (Coordenadora). Trivium e Quadrivium - As artes liberais da idade média. Cotia: Ílbis, I999. 328 p

36 "Algo muito sutil e ao mesmo tempo jucundo é a meditação que instrui os principiantes e exercita os avançados” Hugo de São Vítor. Didascálicon da arte de ler. Petrópolis: Editora Vozes, 200I, vi, I3,p. 265. 
Boenner, Ph. e Gilson, E. História da filosofia cristã. 6a Edição Petrópolis: Editora Vozes, I970. 582 p.

Agostinho. A doutrina cristã. São Paulo: Ed. Paulinas, I99i. 284 p.

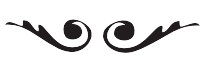

WeSLEY Rodrigues Athayde é graduado em Filosofia pela PUC/sP.

E-mail:wathayde@gmail.com. 